\title{
Good Governance, Public Finance, National Security and Economic Growth in Nigeria: A Discursive Explorational Approach
}

\author{
Ekiran Joseph Ojo (Ph.D)* \\ Department of Economics,School of Arts and Social SciencesCollege of Education, Ikere-Ekiti,Ekiti State, Nigeria \\ *Corresponding Author:Ekiran Joseph Ojo (Ph.D),Department of Economics, School of Arts and Social \\ Sciences College of Education, Ikere-Ekiti, Ekiti State, Nigeria
}

\begin{abstract}
This paper examines the inter-relationships that exist among good governance, public finance, national security and economic growth in Nigeria. A descriptive qualitative survey method was employed in carrying out the research objective of the study. The paper discovered good governance as the panacea for enduring national security and sustainable economic growth and development in the country. The research work concluded that to maintain national security and attain developmental economic growth in Nigeria, good governance that ensures accountability, transparency, sovereignty, civil liberty and rule of law should be given a place of priority in the society. The study therefore suggests that governance in Nigeria should be revitalized, put in place appropriate macroeconomic policies to attain the set economic objectives. At the same time the government should enforce the rule of law and employ good democratic principles to checkmate the current security challenges like herdsmen hazard, religious extremists, kidnapping for ransom and attacks on oil infrastructure in the country.
\end{abstract}

Key words:Good Governance, Public Finance, National Security, Economic Growth.

\section{INTRODUCTION}

Nigeria is poorly ranked on the global scale of governance indicators (Fashagba and Oshewolo, 2014).The country is currently facing a host of complex security challenges such as violent insurgency, herdsmen hazard, piracy, kidnapping for ransom, attacks on oil infrastructure, organized crime and religious extremists. These threats typically involve irregular forces and are largely societal based. According to Omodia (2012), failure of governance is core to the socio- economic and political development challenges confronting Nigeria and the spate of violence that threatens national security.

Security implies protection from danger or other conditions that threaten human life and property. It is in practice to anchor the security of life and property within the sphere of human rights under International Law (Cletus, 2014). Such human rights include Liberty and Security of the person, protection against slavery and servitude, protection against arbitrary arrest and detention. According to the Clarification of United Nations Development Program (UNDP, 2006), the state obligation to respect, protect and fulfill human right is a bench mark for security within any given entity.

Governance means the manner in which power is exercised by governments in the management and distribution of a country's social and economic resources (Ogundiya, 2011). The nature and manner of this distribution makes governance a bad or good one. To Hyden and Agborsangaya (2011), governance is defined as the management of public territory in which state and non-state actors come together to make policy decisions affecting the security and welfare of the citizens.

The emerging cases of insecurity in Nigeria are traceable to rebellious groups like Boko Haram and Herdsmen from the North, Niger Delta Militants from the South-South and MASUB from the East. The emergence of Boko Haram and herdsmen insurgents in Nigeria have not only paralyzed the already bastardized economy but threaten our corporate national existence. According to Edeh and Ugwueze (2014), Boko Haram is currently reinforcing the economic comatose of the Northern Nigeria and therefore impoverishing the people the more and making life unbearable for both the indigenes and non-indigenes who perpetually live in fear thereby re- echoing indigenes insecurity situation and forcing many out of the region. 


\subsection{Statement of the Problem}

The nexus among governance, national security and development variables has generated many studies of different spaces and time coverages that have produced mixed results.Some of the studies are country- specific while others are cross- country. Authors like Fashagba and Oshewolo (2014) and Cletu (2014) worked on the relationship between governance and security in Africa. The nature of governance and security for all countries in Africa cannot be the same and the application of the outcomes form such studies to solve the challenges of one country in the continent may not be appropriate. This study therefore adopts country- specific analysis rather than cross- country analysis, by choosing one single country (Nigeria) with an attempt to make more in- depth investigation that produces valid inferences for robust and unbiased prediction for peace, economic growth and good governance in the country.

Most earlier time studies like Edeh and Ugwueze (2014) used Boko Haram insurgence to proxy insecurity in Nigeria. There are a list of other insurgences like kidnapping, herdsmen hazard and oil infrastructure breaking in the country. A research based on only one insurgence and ignore others may produce bias results.Likewise, most earlier time studies searchedinto the problems of insurgency in the country but excluded public finance variable which is a vital instrument in budgeting for effective planning in the process of providing lasting solution to insecurity of a society. These problems will be solved in this study by incorporating some other types of insurgencies and include public finance variable into research procedures.

President Muhammadu Buhari during a working visit to the United States on $30^{\text {th }}$ April, 2018 said that the Federal government has adopted various multi-sectoral approaches in Nigeria with the view to put an end to the security challenges in the country. He stressed that government agencies have been made to address the socio- economic and political dimensions while the armed force was made to adopt a non- kinetic counter terrorism/ counter insurgency approach code- named "Operation Safe Corridor", to de- radicalize, re- habilitate and re- integrate willing surrendered Boko Haram and other violents groups into the larger society. In spite of the machineries put in place by the government, our societies in Nigeria are not yet free from the problems of insurgencies and economic challenges.

In view of the above identified short comings on the part of some earlier time studies, an attempt is necessary for a current research effort into the issues of governance, security,public finance and economic growth in Nigeria.

\subsection{Objective and the Method of the Study}

The main objective of this study is to examine the inter- relationships among good governance, public finance, national security and economic growth, using discursive philosophical approach. A descriptive qualitative survey method was employed by the study to carry out the research objective.

\section{REVIEW OF Literature AND CONCEPTUAl Clarification}

There have been a plethora of empirical studies on governance, security and development. According to Coker and Genyi (2014), governance is described as the way of exercising power in the management of the country's economic and social resources for the development of a society. Governance embraces the nation's institutional and structural arrangements, policy formation and implementation capacity. Chigbu (2007) presents governance as a process through which the lives and aspirations of the citizenry are collectively pursued for the realization of their maximum potentials. It is the ability of the government to effectively promote the economic well- being of its people.

Governments have the primary responsibilities to ensure that the structures for protection of lives and property, social amenities and development of critical infrastructure are in place for economic progress (Okoye, Omankhanlen, Okoh, Urhie and Ahmed, 2019). Edmund, Choong and Lau (2017) further claimed that government planners should be able to foresee future economic, social and security conditions prior to the implementation of public expenditure policy to attain growth objective.

According to Ogar, Eyo and Arikpo (2019), governments have been found to be involved in two basic functions which are: protection function (security) and provision function (economic development). Expenditure pattern of the government and revenue generation play an important role in the economic 
development of the concerned nation (Uma, Eboh and Nwaka, 2013 and Gumus and Mammadov, 2019).

Good governance, according to Owoeye and Bissessar (1992) consists of the traditions and institutions by which governments are selected, monitored and replaced, the capacity of government to effectively formulate and implement policies; and the respect of citizens and the state institutions that govern the economic and social interactions among them. Edeh and Ugwueze (2014) opines that the only set of problems that cannot be solved by good governance are no- existing ones. By implication, good governance is a panacea for the insecurity and the economic challenges that presently characterize the Nigerian society. It has a base in literature that since early 1990s, good governance has attracted large numbers of international aid donors to some less developed countries who are faced with limited resources to successful economic development (The Social Science Encyclopedia).

Governance can be good or bad. Good governance guarantees the delivery of public goods following equity and transparent principles in the distribution process (Gujarat, 2011). Some of the identities of good governance in a country especially Nigeria are as tabulated below

Table1. Good Governance Parameters

\begin{tabular}{|l|l|l|}
\hline S/N & Parameter & Interpretation \\
\hline 1. & Accountability & $\begin{array}{l}\text { The state where institutions are accountable, responsible and answerable } \\
\text { to those who will be affected by their decisions. }\end{array}$ \\
\hline 2. & Transparency & $\begin{array}{l}\text { The availability and accessibility of information to those who will be } \\
\text { affected by the decision of the stake holders. }\end{array}$ \\
\hline 3. & Rule of Law & $\begin{array}{l}\text { The legal frameworks that are enforced impartially. It means that the } \\
\text { regular law must prevail in all circumstances to foreclose impurity, } \\
\text { arbitrariness and abuse (Okoli and Okpaleke, 2013). This requires an } \\
\text { independent judiciary and an impartial and incorruptible police force. }\end{array}$ \\
\hline 4. & Sovereignty & $\begin{array}{l}\text { The supreme power to rule rests with the people (the electorates). The } \\
\text { situation where people decide who rules them andto change the ruler in } \\
\text { case he fails to live up to expectation (Okoli and Gusau, 2013). }\end{array}$ \\
\hline 5. & Civil Liberty & $\begin{array}{l}\text { The practice of civil rights such as the right to property, freedom to } \\
\text { speech, freedom to the press and the possibility for seeking redress in the } \\
\text { event of any violation of such entitlements. }\end{array}$ \\
\hline 6. & Equity and Inclusiveness & $\begin{array}{l}\text { Impartiality and fairness on the part of citizenry. Here, members of the } \\
\text { society feel that they all have stake and are not excluded from the } \\
\text { mainstream of the society. }\end{array}$ \\
\hline 7. & $\begin{array}{l}\text { Efficiency } \\
\text { Effectiveness }\end{array}$ & $\begin{array}{l}\text { Making the best official use of the available scarce resources to produce } \\
\text { results that meet the needs of the society to enhance set objectives. }\end{array}$ \\
\hline
\end{tabular}

Source: Author's Complication, 2019

If the parameters of good governance as described in Table 1 above among others are put in place in a society, the government in charge will be able to transform the life of the people positively. The welfare packages that shall be produced by such government include the following gains of good governance:

\section{- Sustainable security}

- Sustainable economic growth

- Job creation

- Improved health facility

- Effective education

- Infrastructural development

- Poverty alleviation

Presently, the above mentioned dividends of good governance have constituted serious challenges in Nigeria (Atelhe, 2014).The issues of national insecurity and economic depression are areas of most 
concern in the country. What we witnessing today is the uprising waves of insurgences manifesting in many part of the country in the following forms:

- Boko Haram insurgence in North- East and North- West Nigeria.

- Herdsmen hazard in North- Central Nigeria

- Niger Delta Militants in South- East Nigeria

- Kidnapping for ransom in South- West Nigeria

On the issue of economic well-being, it is confirmed in the literature that the people of Nigeria and all other countries in West Africa are under- nourished (Cletus, 2014). The Table 2 below shows the comparative levels of hunger in Africa between 1969 and 2003.

Table2.Hunger in Africa.

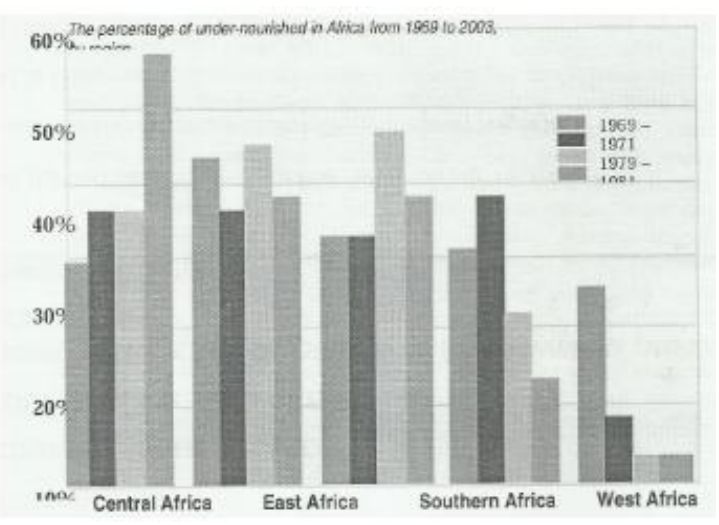

Source: BBC Focus on Africa Vol, 19 No.3 July.

Confirming from the Table 2, Nigeria is relatively poor in spite of the large worth of natural resources being paraded by the country. According to Edeh and Ugwueze (2014), the recent insurgences in Nigeria are attributed to the high level of poverty among the people in the society which are traceable to be the product of bad governance. The question now is, what is the way out of these insecurity and economic challenges in the country? This question leads us to the next section of this paper as presented below.

\section{ANALYSIS OF THE INTER-RELATIONSHIPS AMONG THE STUDY'S VARIABLES.}

\subsection{Presentation of the Inter-Relationships among Governance, Public Finance, Security and Economic Growth in Nigeria}

There are strong inter-relationships among good governance, effective public finance national security and economic growth of a nation. Economic growth is a function of sustainable national security and likewise the national security is derived from good governance through effective public finance and vice versa. The debate on theinter- relationships between the four research variables among others are demonstrated in figures 1 and 2 below:

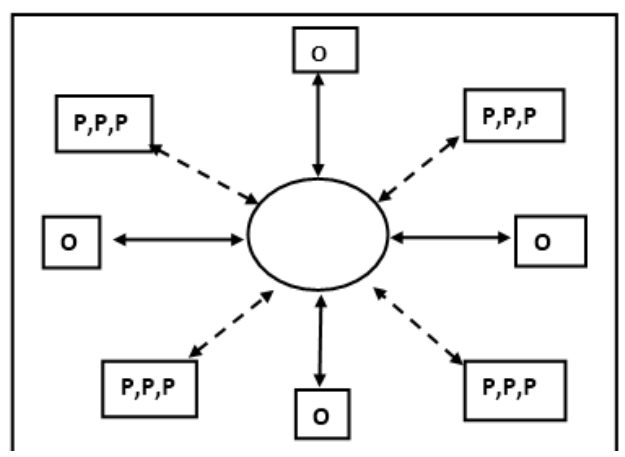

Figure1.Showing the impact of Good Governance on National Security and Economic Growth.

Source: Author's Conceptualization, 2019. 
From the figure 1 above, the central big circle represents a country with good governance leadership. The small circles represent the effective resource-generating sectorswhich are products of the operative public finance of the country. Letter ' $\mathrm{P}$ ' are the people looking up to the country for their survival. The lines linking the small circles with the big circle represent the channels through which the country finances the resources sectors and the receipt of revenues from the sectors. The dotted lines indicate the medium through which the country gives the revenue she collects from the nation's resource-generating sectors back to the people and the services rendered by the people in return.

The more the resource-generating sectors and their rate of efficiency, the more the nation generates revenues and the more she gives back to the people. The situation will result to sustainable security and long-run economic growth and development in such society under good governance. These analogies are in line with the position of Edeh and Ugwueze (2014) who claimed that good governance through legitimacy, transparency and accountability will engineer the resource-generating sectors that will attain the set objectives of a society.

\subsection{Discussion of Findings}

The above figure 1 can be discussed with the aid of figure 2 as detailed below.

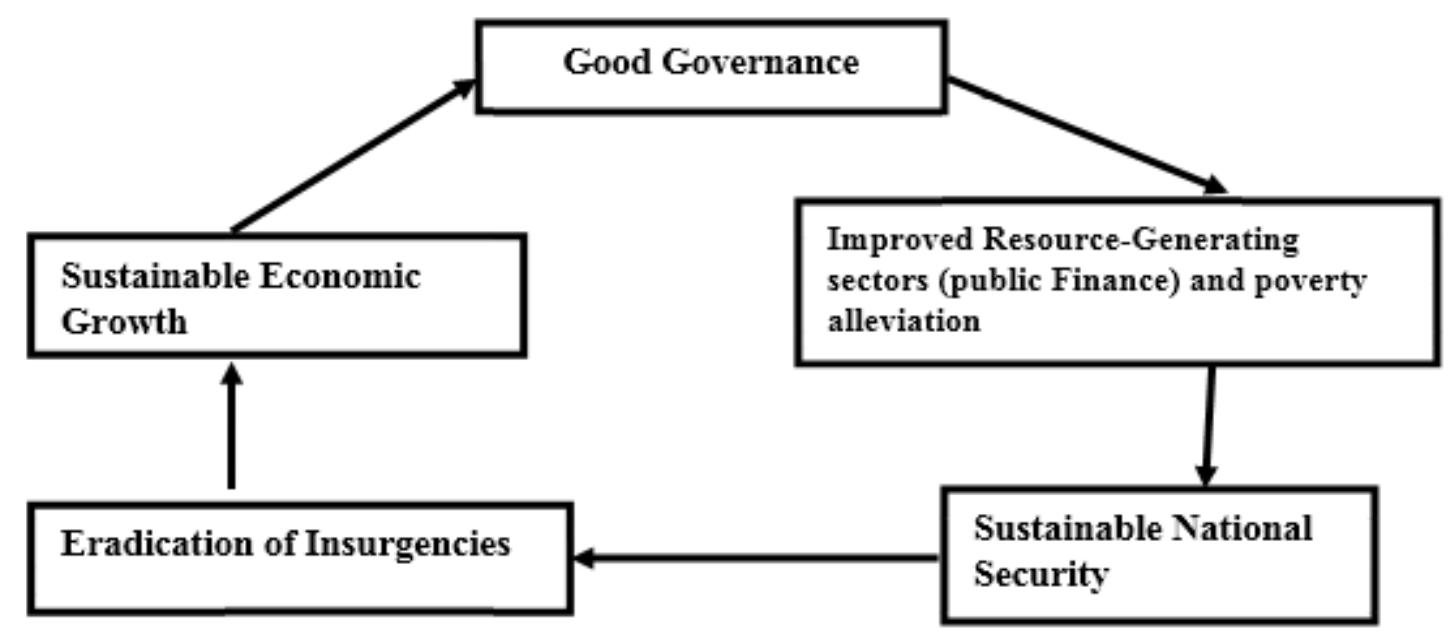

Figure2. Reflecting the inter-relationships among Good Governance, improved Public Finance,National Security and Economic Growth.

\section{Source: Author's Conceptualization, 2019}

As demonstrated in the conceptualized figure 2 above, good governance when put in practice in a country like Nigeria will automatically engineer an improved resource-generating sectors througheffective public finance of the country. One of the features of good governance is efficiency especially in budgetary allocation.For this reason, the country will channel the increased revenues toward poverty alleviation which will ceteris parabus ensure sustainable national security that implies eradication of insurgencies in that country.

If the problem of security challenges in Nigeria is solved, herdsmen hazard, kidnapping for ransom and attacks on oil infrastructure among other insurgencies will stop. These will lead to increments in farm products, labor productivity and oil revenue in the country. As indicated in the figure 2 therefore, eradication of insurgencies in Nigeria will produce sustainable economic growth which is a major parameters of accessing good governance in a society.

\section{CONCLUSION}

This paper is aimed at examining the inter-relationship that exists among good governance, public financenational security and economic growth and development in Nigeria. The study affirms that these four research variables in the country are closely related and intertwined.

The study concludes that economic growth cannot thrive and persist where peace and security is a luxury to the citizenry. No potential investor will risk investment in a volatile society that is characterized with violent insurgencies. In this direction, this paper is in agreement with Coker and 
Genyi (2014) that most investors and potential ones have stayed off Nigeria due to the endless pronounced security challenges in the country.

The paper further observed that Nigerians have not be able to enjoy the required good governance where the national resources are budgeted to address people's poverty, illiteracy, ignorance and other forms of vulnerabilities. The study finally concluded that if good governance is in place in Nigeria more revenue will come into the government purse, poverty will be reduced, peace and security will lead to economic sustainability in the country.

\section{SugGestions}

This work by conceptualization observed that good governance is justified by poverty alleviation, sustainable security and economic growth and development. The study observed that governance in Nigeria has not able to produce the obtainable bench mark. To reposition the country to expectation, the following suggestions are offered:

- The law makers should enact the appropriate laws and the judiciary should be more pro-active in checkmating the excesses of the electors and electees in order to produce suitable leaders for good governance in Nigeria.

- Government should put in place appropriate fiscal policies to declare emergency on job creation as a way of removing hunger and poverty with the intension of eradicating insurgencies as well as attaining economic growth objective in the country.

- Government should enforce the rule of law on the principles of accountability and transparency in leadership for good governance as well as checkmating the ongoing insurgencies like kidnapping for ransom and herdsmen hazardin the country.

- Government should enact and implement appropriate laws to address all forms of corrupt practices in the process of building strong revenue base for the country.

- Education is an imperative force if good governance, peaceful environment and sustainable economic growth are desired in Nigeria. Government should therefore place budgetary priority on educational investment to remove ignorance syndrome in the country.

\section{REFERENCES}

[1] Atelhe, G.A. (2014). Democracy and National Security in Nigeria: A Discursive Exploration, Mediterranean Journal of Social Sciences, 5 (4), 495-499.

[2] Chigbu, U. (2007). Nigeria's World Feature Article-Viewing Nigeria's Bad Governance in the context of Bad Fellowship, retrieved from: http://nigerworld.com.articles/2007/doc/031.html.

[3] Cletu, I.A. (2014). Governance and Security in Africa in the $21^{\text {st }}$ Century: A Political Economy Perspective, Journal of Alternative Perspectives in the Social Sciences, 5(4), 783- 807.

[4] Coker, M.A. \&Genyi, M.G. (2014). Bad Governance: The Bane of Peace, Security and Sustainable Development of Nigeria, International Journal of Development and Sustainability, 3 (5), 1121-1146.

[5] Edeh, H.C. \&Ugwueze, M.I. (2014). Good Governance, National Security and Economic Development in Nigeria: A Political Diagnosis of Boko Haram Insurgence, Mediterranean Journal of Social Sciences, 5 (17), 33-38.

[6] Edmund, L. K., Choong, C. K., \& Lau, L. S. (2019). Government Expenditure, Efficiency and Economic Growth: A panel Analysis of Sub-Saharan African Low Income Countries. African of Economic Review, $\mathrm{v}(\mathrm{II}), 34-54$

[7] Fashagba, J.O. \&Oshewolo, S. (2014). Peace and Governance in Africa, Covenant University Journal of Politics and International Affairs, 2 (2), 45-57.

[8] Gujarat, (2011). Discussion Forum on Good Governance Concept Paper. Gujarat $5^{\text {th }}$ Global Summit, held at GNLU Campus, E-4, GIDC Electronic Estate, Sector 26, Gandhinagar, Gujarat, India.

[9] Gumus, E., \& Mammadov, R. (2019). Real Government Expenditure and Economic Growth in the Southern Caucasus Countries: A Panel Data Analysis. Khazar Journal of Humanities and Social Sciences, 22(2), 20-34.

[10] Hyden, G. \&AgborsangayaFiteu (2011). Diagnostic Tools for Governance in Fragile State: Lessons, Trends and Suggestions. Social Development Department. IBRD/ World Bank 
Good Governance, Public Finance, National Security and Economic Growth in Nigeria: A Discursive Explorational Approach

[11] Ogar, A. E., Eyo, I. E., \& Arikpo, O. F. (2019). Public Expenditure and Economic Growth in Nigeria. VAR Approach. European Journal of Economic and Financial Research, 3(3), 36-60.

[12] Ogundiya, I. S. (2010). Democracy and Good Governance: Nigeria's Dilemma, African Journal of Political Science and International Relations, 4(6).

[13] Okoli, A.C. \&Gusau, A.S. (2013). Lecture Mimeograph, Department of Political Science, Federal University, Lafia, Nigeria.

[14] Okoli, A.C. \&Okpaleke, N.F. (2013). Federalism in Nigeria: Some Reflections, NASHER Journal of Multidisciplinary research, 1 (1).

[15] Okoye, L. M., Omankhanlen, A. E., Okoh, J., Urhie, E., \& Ahmed, A. (2019). Government Expenditure and Economic Growth: The case of Nigeria. Proceedings of SOCIOINT 2019- $6^{\text {th }}$ International Conference of Education, Social Sciences and Humanities 24-26 June 2019-Istanbul, Turkey, 1184-1194.

[16] Omodia, S. M. (2012). Political Leadership and National Security in the Nigerian Fourth Republic: A Discourse, African Journal of Sciences, 2(4), 90- 96.

[17] Owoye, O. \&Bissessar, N. (1992). Bad Governance and Corruption in Africa: Symptoms of Leadership and Institutional Failures, Commission for Asia and Pacific.

[18] The Social Science. Encyclopedia (1996). 2nd Edition, London: Routledge.

[19] Uma, K. E., Eboh, F. E., \& Nwaka, I. D. (2013). Government Expenditure in Nigeria: Effect on Economic Development. American Journal of Social Issues and Humanities, 3(3), 119-131.

[20] World Bank (1998). Sub-Saharan Africa: from Crisis to Sustainable Growth, Washington: World Bank.

\section{AUTHORS' BIOGRAPHY}

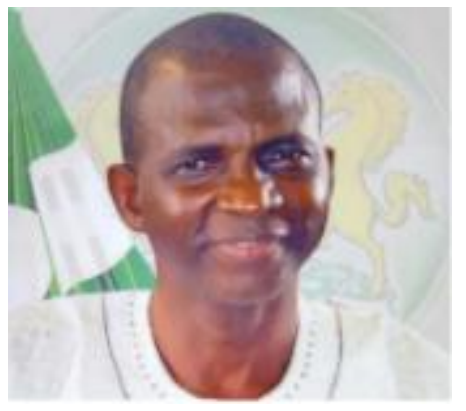

Ekiran Joseph Ojo is a lecturer in the Department of Economics, School of Arts and Social Sciences, College of Education, Ikere-Ekiti, Ekiti State, Nigeria.

Citation:Ekiran Joseph Ojo (Ph.D). "Good Governance, Public Finance, National Security and Economic Growth in Nigeria: A Discursive Explorational Approach" International Journal of Humanities Social Sciences and Education (IJHSSE), vol 7, no. 4, 2020, pp. 31-37. doi: http://dx.doi.org/10.20431/23490381.0704004.

Copyright:@ 2020 Authors. This is an open-access article distributed under the terms of the Creative Commons Attribution License, which permits unrestricted use, distribution, and reproduction in any medium, provided the original author and source are credited. 